The Canadian Mineralogist

Vol. 43, pp. 479-493 (2005)

\title{
PROLONGED EXISTENCE OF SULFIDE MELT IN THE BROKEN HILL OREBODY, NEW SOUTH WALES, AUSTRALIA
}

\author{
B. RonALD FROST ${ }^{\S}$, SUSAN M. SWAPP AND ROBERT W. GREGORY \\ Department of Geology and Geophysics, University of Wyoming, Laramie, Wyoming 82071, U.S.A.
}

\begin{abstract}
The Broken Hill orebody, in Australia, is hosted in pelitic and psammitic gneisses that underwent metamorphism in the granulite facies. Peak metamorphism in the area occurred around $1600 \mathrm{Ma}$ and exceeded temperatures of $850^{\circ} \mathrm{C}$ at pressures of 5-7 kilobars. The orebody is located in an area of intense deformation that occurred 5 to 15 million years after the peak metamorphism. Highly foliated pelitic schist directly adjacent to the Broken Hill orebody contains assemblages ranging from quartz K-feldspar - biotite - garnet - sillimanite to quartz - muscovite - biotite - staurolite - garnet - chlorite. The latter assemblage equilibrated at temperatures as low as $600^{\circ} \mathrm{C}$. Silicates in the low-temperature assemblages are intimately associated with galena that, in places contains clusters rich in $\mathrm{Ag}$ and $\mathrm{Sb}$ alloys, sulfides, and sulfosalts. One-bar experiments in the system $\mathrm{Ag}-\mathrm{Sb}-\mathrm{S}$ indicate that the assemblages seen in these rocks would have been molten at $500^{\circ} \mathrm{C}$. These relations suggest that a polymetallic melt persisted at Broken Hill for up to twenty million years after peak metamorphism.
\end{abstract}

Keywords: metamorphism, orebody, massive sulfides, melting, Broken Hill, Australia.

\section{SOMMAIRE}

Le gisement de Broken Hill, en Australie, est situé dans un hôte gneissique métapélitique et métapsammitique qui a subi un métamorphisme au faciès granulite. Le paroxysme métamorphique dans la région a eu lieu il y a environ 1600 millions d'années, et a impliqué une température au delà de $850^{\circ} \mathrm{C}$ à une pression entre 5 et 7 kilobars. Le gisement est situé dans une zone de déformation intense active de 5 à 15 million d'années après la culmination métamorphique. Des schistes pélitiques fortement foliés directement adjacents au gisement de Broken Hill contiennent des assemblages allant de quartz - feldspath potassique biotite - grenat - sillimanite à quartz - muscovite - biotite - staurolite - grenat - chlorite. Ce deuxième assemblage s'est équilibré à une température aussi basse que $600^{\circ} \mathrm{C}$. Les silicates des assemblages de plus faible température sont intimement associés à la galène qui, par endroits, contient des amas riches en alliages, sulfures et sulfosels d'argent et d'antimoine. Des expériences à un bar dans le système $\mathrm{Ag}-\mathrm{Sb}-\mathrm{S}$ indiquent que les assemblages de ces roches pourraient avoir été à l'état fondu à $500^{\circ} \mathrm{C}$. Ces relations font penser qu'un liquide polymétallique a persisté à Broken Hill jusqu'à vingt millions d'années après la culmination métamorphique.

(Traduit par la Rédaction)

Mots-clés: métamorphisme, gisement, sulfures massifs, fusion, Broken Hill, Australie.

\section{INTRODUCTION}

The Broken Hill $\mathrm{Pb}-\mathrm{Zn}-(\mathrm{Ag})$ ore deposit, the largest $\mathrm{Pb}-\mathrm{Zn}$ deposit in the world, is hosted in granulitegrade gneisses of the Broken Hill block. Because the orebody has been intensely deformed and subjected to high-grade metamorphism, its origin and evolution have been subjects of considerable debate (Parr \& Plimer 1993). Early authors postulated an epigenetic origin for the orebody (Gustafson et al. 1950), but the prevailing model is that the orebody is a metamorphosed sedimentary-exhalative (SEDEX) deposit (Parr \& Plimer 1993).
Although the $\mathrm{Pb}, \mathrm{Zn}$ and $\mathrm{Ag}$ may have been originally concentrated in a sedimentary environment, their distribution within the deposit was probably modified considerably during metamorphism. For example, Lawrence (1967) postulated that some portions of the orebody were remobilized in the form of "sulfide neomagmas" during metamorphism. This hypothesis has received little attention in the past 30 years, but recent experimental work (Mavrogenes et al. 2001) and textural studies (Frost et al. 2002) indicate that the Broken Hill orebody was partially molten at peak metamorphism. As part of a study to the determine the role of

§E-mail address: rfrost@uwyo.edu 
melts in the evolution of the Broken Hill orebody, we have undertaken a detailed study of the metamorphism in the vicinity of the deposit.

The orebody lies within the Broken Hill block in New South Wales, which is considered to be one of the classic granulite terranes of the world (Binns 1964). The andalusite-bearing pelitic schists in the northern margin of the block grade southward into sillimanite-cordierite gneisses that are associated with orthopyroxene-bearing mafic granulites that record metamorphism in the five to six kilobar range (Phillips 1980). Because retrograde shear-zones containing kyanite and staurolite cut the granulites, Phillips \& Wall (1981) concluded that the Broken Hill area underwent nearly isobaric cooling. This conclusion was supported by Powell \& Downes (1990) on the basis of phase relations in garnet- and cordierite-bearing anatectic gneisses near the town of Broken Hill.

\section{Regional Geology}

The Broken Hill block is an exposure of Proterozoic supracrustal rocks that crops out over an area of about $5,000 \mathrm{~km}^{2}$ in western New South Wales (Fig. 1). Most of the block is underlain by the Paleoproterozoic Willyama Supergroup. To the north, these rocks are unconformably overlain by the Neoproterozoic sedimentary rocks of Adeladean age. The Willyama Supergroup consists of a sequence of metamorphosed clastic sedimentary units that were deposited in a developing rift. The thickness of the sequence is unknown because of the intense deformation in the area; it is probably in the range of 4,500 to 13,000 meters (Willis et al. 1983). All units from the Willyama Supergroup contain detrital Archean zircon with ages as old as $3.2 \mathrm{Ga}$ (Raetz et al. 2002), indicating that the supergroup was deposited on or near Archean basement. However, no outcrops of an Archean basement to the sequence have been recognized.

\section{Stratigraphy of the Willyama Supergroup}

The lowest stratigraphic units of the Willyama Supergroup are exposed to the east and southeast of Broken Hill. These have been subdivided into the lower Clevedale Migmatite and the upper Thorndale Composite Gneiss. The Clevedale Migmatite is dominantly a quartzofeldspathic migmatite, whereas the Thorndale Composite Gneiss includes pelitic horizons containing garnet, sillimanite and cordierite. Both units have been intruded by mafic dikes, which are now metamorphosed to the granulite or upper amphibolite facies. Detrital grains of zircon give a maximum age of deposition for these rocks in the range of 1830-1850 Ma for the Thorndale Composite Gneiss (Page et al. 2005).

The Thackaringa Group consists of metapelitic and metapsammitic gneiss, much of it albitized, with minor amounts of iron formation and quartz-garnet rocks. As with the underlying gneisses, the Thackaringa Group contains metamorphosed mafic dikes and sills. It has also been intruded by a granitic pluton, the Alma gneiss, which is dated at $1704 \pm 3 \mathrm{Ma}$ (Page et al. 2005). Detrital grains of zircon indicate that the maximum age of deposition of the Thackaringa Group is $1730 \mathrm{Ma}$ (Page et al. 2005). The Thackaringa Group thus was deposited between 1730 and 1700 Ma.

The Broken Hill Group consists of the metasedimentary rocks that host most of the $\mathrm{Pb}-\mathrm{Zn}$ deposits of the district, including the massive ( $c a .280 \mathrm{Mt}$ ) Broken Hill deposit. The unit consists dominantly of metapelitic to metapsammitic metasedimentary gneisses, minor calcsilicate rocks, felsic metavolcanic units, and iron formations. Grains of zircon from the felsic metavolcanic rocks within the upper Broken Hill group have been dated at $1685 \pm 3 \mathrm{Ma}$ (Page et al. 2005); this is within error of dates based on zircon from mafic sills from Round Hill, which are $1683 \pm 5$ Ma old (Nutman \& Ehlers 1998). Zircon from tuffaceous metasedimentary units in the lower Broken Hill Group gives an age of $1693 \pm 4 \mathrm{Ma}$ (Page et al. 2005). These rocks may have provided the heat source for the hydrothermal fluids that produced the Broken Hill deposit; they constrain the age of deposition of the Broken Hill Group to a short period of time between 1695 and $1685 \mathrm{Ma}$.

The Sundown Group is a metamorphosed sequence of pelitic and psammitic gneisses that overlies the Broken Hill Group. Although the rocks of the Sundown Group are lithologically similar to those of the Broken Hill Group, the Sundown Group lacks the metamorphosed mafic sills and dikes that are abundant in older stratigraphic units. The age of deposition for the Sundown group thus is much more poorly constrained than is that of the Broken Hill Group. On the basis of detrital zircon ages, Page et al. (2005) concluded that Sundown Group was deposited around $1670-1680 \mathrm{Ma}$.

The youngest sedimentary units in the Willyama Supergroup constitute the Paragon Group. It is characterized by graphitic metasedimentary rocks with a minor calc-silicate horizon. The Paragon Group is restricted to the northern portions of the Broken Hill block and is not exposed in the area encompassed by Figure 1. The age of deposition for the Paragon Group is constrained to lie between 1640 and $1660 \mathrm{Ma}$ (Page et al. 2005).

\section{STRUCTURE}

Four major events of deformation are recognized within the Broken Hill block (Laing et al. 1978, Hobbs et al. 1984, Wilson \& Powell 2001). The $\mathrm{D}_{1}$ event is recorded as isolated isoclinal folds that are associated with an S-surface that is roughly parallel to compositional layering. White et al. (1995) recognized the existence of abundant high-temperature shear zones that contain the high-grade assemblage Qtz + Kfs + Sil + $\mathrm{Grt}+\mathrm{Bt}$ (abbreviations after Kretz 1983). On the basis 
of the sense of motion on these shear zones, they maintained that the $\mathrm{D}_{1}$ deformation might have been related to northwest-verging thrusting. More recent work by Gibson \& Czarnota (2003) suggests that these structures may have been associated with extension. The $\mathrm{D}_{2}$ event formed a steeply dipping foliation that strikes northsouth in the northern part of the block, and northeastsouthwest in the southern part; locally, it obliterates the $\mathrm{D}_{1}$ structures. The $\mathrm{D}_{2}$ event occurred at slightly lower temperatures than $\mathrm{D}_{1}$ (Majoribanks et al. 1980). In the mine area, the $D_{2}$ fold axes are folded into a broad $D_{3}$ antiform that locally carries a penetrative retrograde $\mathrm{D}_{3}$ schistosity (Laing et al. 1978).

The Broken Hill Block is cross-cut by numerous retrograded shear-zones, which, because of their high mica content, are locally known as schist zones. The larger zones may be several hundred meters wide and more than 50 kilometers long. Displacement across these schist zones is unknown, but it is likely to be substantial (Hobbs et al. 1984). Near the schist zones, the older fabrics are overprinted by a fabric that may contain garnet, staurolite, kyanite, or chlorite. In this paper, we will refer to the schist zones as $\mathrm{D}_{4}$, although they may have experienced numerous periods of deformation.

The metasedimentary rocks around the Broken Hill orebody locally contain graded bedding, the orientation of which indicates that they have been overturned. This is assumed to be due to a $D_{1}$ fold, although the axis of this fold itself has not been identified (Laing et al. 1978). The rocks have then been folded into three major $\mathrm{D}_{2}$ structures, the Hanging Wall Synform, the Broken Hill Antiform, and the Broken Hill Synform (Laing et al. 1978) (Fig. 1). The Broken Hill orebody lies within the Broken Hill antiform, though the antiformal axis commonly is sheared out along both $\mathrm{D}_{2}$ and $\mathrm{D}_{3}$ structures (Laing et al. 1978). A major $\mathrm{D}_{4}$ structure, the GlobeVauxhall shear, lies 1 to 1.5 kilometers northwest of the orebody, and the orebody is cut by two smaller northtrending $\mathrm{D}_{4}$ faults.

\section{METAMORPHISM}

As many as four metamorphic events have been postulated in the Broken Hill area (Stüwe \& Ehlers 1997, Wilson \& Powell 2001). In most schemes of classification, the events have been correlated with the various deformation-induced fabrics in the rocks. Page et al. (2005) maintain that because there is a relatively short period of time involved in the development of the $D_{1}$, $\mathrm{D}_{2}$ and $\mathrm{D}_{3}$ structures, there is no compelling reason to assume that the metamorphism associated with these fabrics consists of multiple thermal pulses. We will treat the metamorphism as part of a single thermal event and conclude that the area underwent two main metamorphic events. The first is the regional metamorphism that is broadly associated with the $\mathrm{D}_{1}, \mathrm{D}_{2}$ and $\mathrm{D}_{3}$ fabrics, and the second is a retrograde metamorphism that is associated with the lower-grade shear-zones.
The regional metamorphism increases in grade from north to south (Binns 1964, Phillips 1980) (Fig. 2). The lowest-grade rocks, in the northern portion of the Broken Hill block and in the northeast of the Euriowie block, contain the assemblage And + Ms. With increasing grade, andalusite goes to sillimanite while muscovite is still present in the rocks. This produces a narrow zone of Sil + Ms between the andalusite zone and the Sil + Kfs zone (Fig. 2). These relations mean that metamorphism in the lower-grade portion of the Broken Hill block took place at pressures slightly above those of the intersection of the andalusite-sillimanite boundary with the upper stability of Ms + Qtz. For $\mathrm{P}\left(\mathrm{H}_{2} \mathrm{O}\right)=\mathrm{P}_{\text {total }}$, this intersection lies at 2.2 kilobars if one uses the $\mathrm{Al}_{2} \mathrm{SiO}_{5}$ triple point of Holdaway (1971), or 3.0 kilobars if one uses the $\mathrm{Al}_{2} \mathrm{SiO}_{5}$ triple point of Pattison (1992). These pressures would be lower if $\mathrm{P}\left(\mathrm{H}_{2} \mathrm{O}\right)$ were less than $\mathrm{P}_{\text {total }}$. Most of the central and southern part of the Broken Hill block lies within the granulite facies, as indicated by the coexistence of orthopyroxene and augite in mafic dikes within the region. Thermobarometry by Phillips \& Wall (1981) shows a general increase in pressure and temperature toward the southeast, with the highest-grade conditions reaching around $800^{\circ} \mathrm{C}$ and 6 kilobars.

Retrogression is widespread in the Broken Hill block. Over much of the block, the $\mathrm{D}_{2}$ structures contain assemblages indicative of a lower temperature than the peak metamorphism. Retrogression associated with abundant muscovite is common in $\mathrm{D}_{3}$ structures, and is most intense in and near the schist zones. On the basis of the mineral assemblages encountered in the regional metamorphism and in the retrograde shear-zones, Phillips \& Wall (1981) postulated that the Broken Hill area underwent an anti-clockwise $\mathrm{P}-\mathrm{T}$ path during metamorphism.

\section{Timing of the Metamorphism and Deformation}

The peak metamorphism and the $\mathrm{D}_{1}, \mathrm{D}_{2}$ and $\mathrm{D}_{3}$ events at Broken Hill occurred around 1600 Ma during a period of time that is barely resolvable by present dating (Fig. 3) (Page et al. 2005). Page et al. noted that the $\mathrm{D}_{3}$ event is constrained to have occurred after the emplacement of the Cusin Creek pluton $(1596 \pm 3 \mathrm{Ma})$ and the Purnamoota Road leucogneiss (1597 $\pm 3 \mathrm{Ma}$ ), both of which carry $\mathrm{D}_{3}$ fabrics. Event $\mathrm{D}_{3}$ must also have occurred before the emplacement of the Mundi Mundi intrusion (1591 $\pm 5 \mathrm{Ma}$ ), which cuts $\mathrm{D}_{3}$ fabrics (Fig. 3). The $D_{2}$ event occurred before the emplacement of the Cusin Creek pluton and after the emplacement of the Purnamoota Road leucogneiss, which carries a $\mathrm{D}_{1}$ fabric. Because $\mathrm{D}_{2}$ occurred after peak metamorphism, this peak must have occurred before the youngest age for the Cusin Creek pluton (1593 Ma). The oldest possible age for peak metamorphism is $1606 \mathrm{Ma}$, which is the oldest age reported for metamorphic zircon from the Broken Hill area. Because $\mathrm{D}_{1}$ occurred near the peak of metamorphism, the age constraints for $\mathrm{D}_{1}$ are the same 


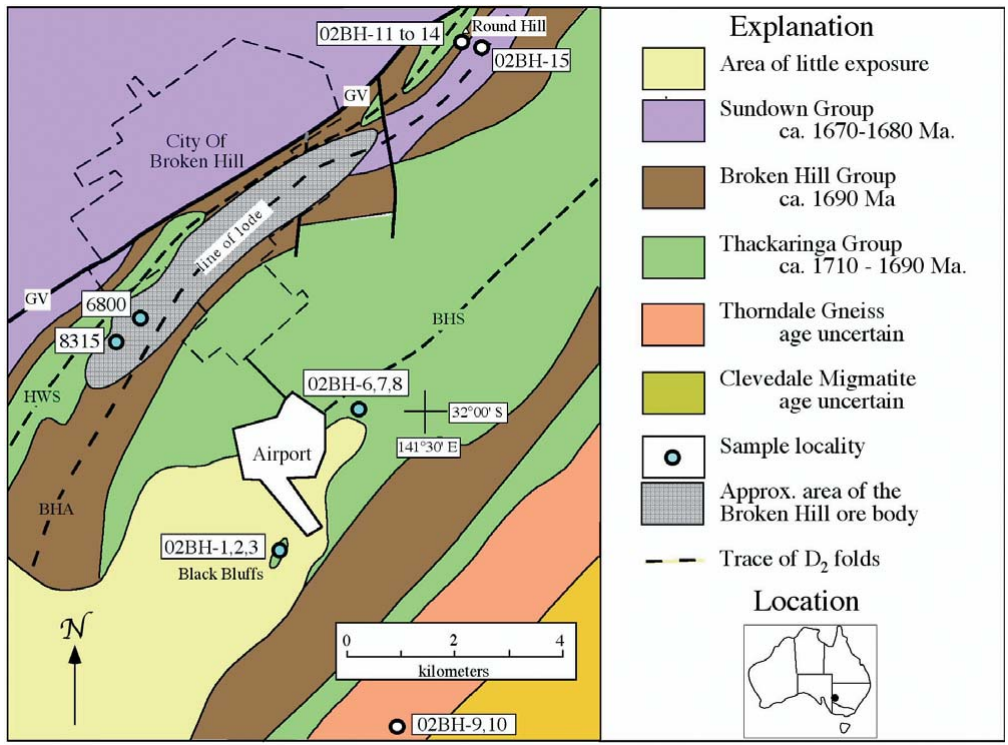

FIG. 1. Map of the Broken Hill area showing regional geology and the areas sampled in this study. Inset shows the location of the area in Australia. BHA: Broken Hill Antiform, BHS: Broken Hill Synform, GV: Globe Vauxhall shear zone. HWS: Hanging Wall Synform. Geology after Willis et al. (1983).

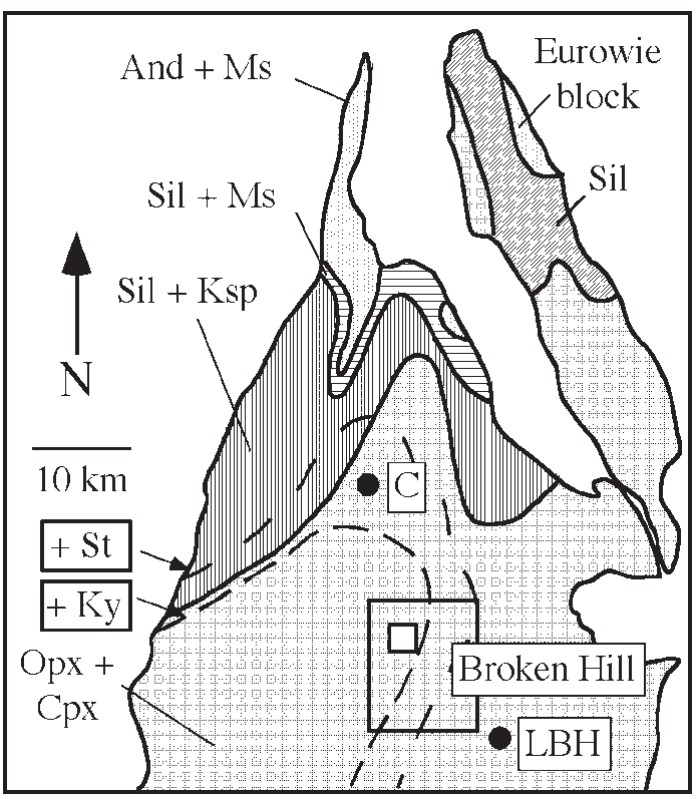

FIG. 2. Map of the Broken Hill and Euriowie blocks showing the metamorphic zones for the prograde metamorphism, and isograds for the retrograde metamorphism. Small box gives the location of Figure 1. Abbreviations refer to locations shown in Figure 3; C: Champion, LBH: Little Broken Hill. After Phillips (1980) and Stevens et al. (1988).

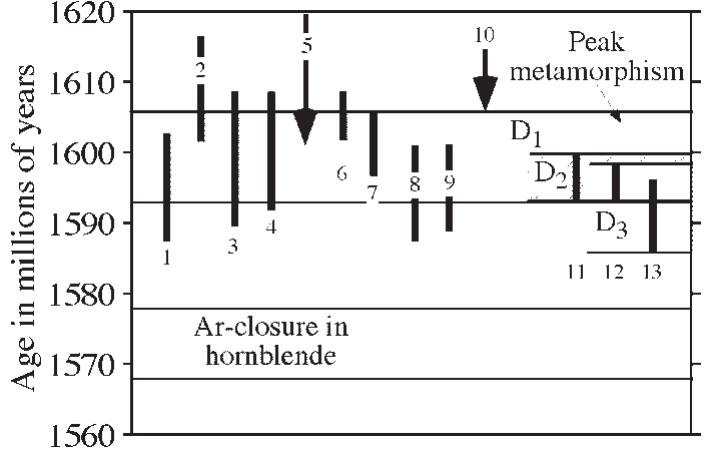

FIG. 3. Geochronology of deformation and metamorphism in the Broken Hill area. Except where noted, all data are U$\mathrm{Pb}$ dates on metamorphic zircon reported by Page et al. (2005). 1. U-Pb date on monazite and titanite from Rasp Ridge Gneiss, a felsic gneiss within the Broken Hill Group (Gulson 1984); 2. Rasp Ridge Gneiss; 3. U-Pb date on monazite from Hores Gneiss (a felsic gneiss within the Broken Hill Group (Page \& Laing 1992); 4. Hores Gneiss (Page \& Laing 1992); 5. Alma gneiss (maximum age); 6, 7. Leucocratic gneiss from Redan geophysical zone, an area on the southeastern portion of the Broken Hill block whose stratigraphic relation to the rest of the block is uncertain; 8 . Amphibolite in the Parnell Formation (a unit in the Broken Hill Group); 9. Himalaya Formation (a unit within the Thackaringa Group); 10. Thorndale Composite Gneiss (maximum age); 11. Crystallization age for the Purnamoota Road granite; 12. Crystallization age for the Cusin Creek pluton; 13. Crystallization age for the Mundi Mundi intrusion. 
as those for the peak metamorphism (1606-1593 Ma). $\mathrm{Ar}-\mathrm{Ar}$ ages in hornblende indicate that the ambient temperature of the area had cooled below $\mathrm{ca} .500^{\circ} \mathrm{C}$ by 1573 $\pm 5 \mathrm{Ma}$ (Harrison \& McDougall 1981). The schist zones appear to have been active at various times in the late Proterozoic and early Phanerozoic. $\mathrm{Nd}-\mathrm{Sm}$ and $\mathrm{Pb}-\mathrm{Pb}$ ages for garnet from the schist zones give ages of $c a$. 500, 880, and $1330 \mathrm{Ma}$ (Dutch \& Hand 2003, Hand et al. 2003, Tonelli et al. 2003).

\section{Sample Locations and Descriptions}

\section{The ore package at Broken Hill}

The ore at Broken Hill occurs in six lenses that extend for more than 10 kilometers along the line of lode. The ore is enclosed within a suite of rocks that is distinctive from the surrounding gneisses. Hodgson (1975) subdivided this suite into ten types, four of which are various types of pyroxenoid-bearing rocks. We have
DH6800

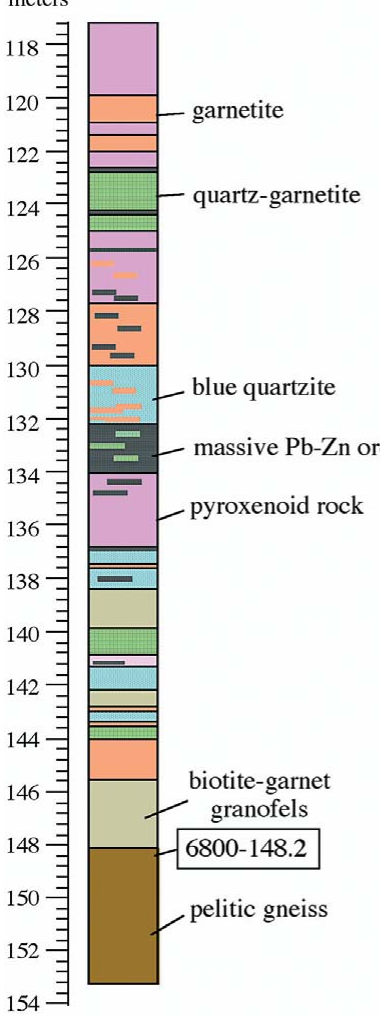

DH 8315

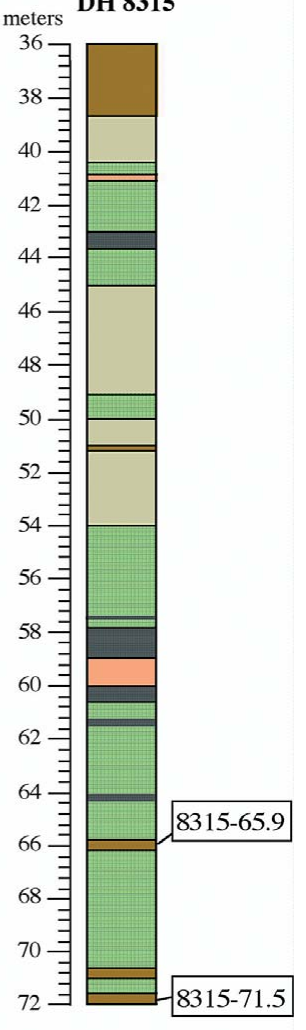

FIG. 4. Diagrams showing rock units encountered and the location of samples studied in drill cores drill cores 6800 and 8315 through the Broken Hill orebody. Location of the cores are shown in Figure 1. divided it into five types (Fig. 4): pyroxenoid rocks, garnetite, quartz garnetite, blue quartzite, and biotitegarnet granofels, and consider them, along with the massive $\mathrm{Pb}-\mathrm{Zn}$ sulfide ore, to form the ore package. The pyroxenoid rock consists of coarse-grained $(>1 \mathrm{~cm})$ pyroxenoids and pyroxenes. The most commonly found mineral in the pyroxenoid rock is rhodonite, but bustamite and Mn-rich clinopyroxene also are found. Wollastonite, calcite, pyroxmangite, and Mn-rich olivine are less widespread. The garnetite is a friable pink rock that is made up entirely of mm-sized grains of $\mathrm{Mn}$ rich garnet. The quartz garnetite, blue quartzite, and biotite-garnet granofels are mutually gradational. With an increase in garnet, the blue quartzite grades into quartz garnetite, and with an increase in biotite and garnet, it grades into biotite-garnet granofels.

The relationship among the rocks in the ore package is complex (Hodgson 1975). Generally, the high-grade ore is associated with the pyroxenoid rock and the garnetite; it is less commonly associated with the quartz garnetite rock. The quartz - biotite - garnet granofels and the garnet - quartz rocks commonly lie between the ore-bearing rocks and the pelitic and semipelitic country-rock (Fig. 4).

\section{Drill-core samples}

In this project, we collected samples from two drill holes that penetrated the western portion of the Broken Hill orebody and that contain well-foliated pelitic rocks with low-variance assemblages that are in direct contact with the ore package (DDH 6800, and 8315) (Fig. 4).

Drill hole 6800 was put down approximately horizontally at 600 meters below ground surface into the Western A lode, a zinc-rich lode in the orebody. Sample 6800-148.2 comes from the western margin of the Western A lode and lies adjacent to quartz - biotite garnet granofels (Fig. 4). The rock contains strongly foliated horizons rich in biotite, sillimanite, and garnet surrounding augen of K-feldspar. Locally, late finegrained muscovite rims the sillimanite. Plagioclase is absent from the rock. Ilmenite is the major opaque phase, though minor pyrrhotite and galena are present as well. Because muscovite is not a foliation-forming phase, as it is in $\mathrm{D}_{3}$ structures, we consider the foliation in this sample to be related to $D_{2}$.

Drill hole 8315 was drilled horizontally about 800 meters below the surface and 600 meters southwest of DH 6800. Samples 8315-65.9 and 8315-71.1 come from the western margin of the Western A lode. Sample 8315-65.9 comes from a meter-wide zone of pelitic schist included within quartz garnetite, whereas 831571.1 comes from the margin of the ore package against quartz garnetite. Both samples contain microlithons of $\mathrm{Qtz}+\mathrm{Bt}+\mathrm{Grt}$ that are separated by anastomosing folia containing $\mathrm{Ms}+\mathrm{Sil}+\mathrm{Grt}+\mathrm{St}+\mathrm{Qtz}$. Plagioclase is absent, and late chlorite is commonly found on the mar- 
gins of the muscovite-rich folia. Because of the intense development of muscovite on the schistosity planes, we interpret the foliation to be related to $\mathrm{D}_{3}$. Ilmenite and pyrrhotite are the major opaque phases in sample 831571.1. Sulfides are more abundant in 8315-65.9, where they occur as localized pockets of galena, pyrrhotite and chalcopyrite that may be associated with chlorite, staurolite, or garnet. Some of the sulfide pockets in 831565.9 contain concentrations of $\mathrm{Ag}$ and $\mathrm{Sb}$. In these pockets, we have identified the phases argentite or acanthite $\left(\mathrm{Ag}_{2} \mathrm{~S}\right)$, and dyscrasite $\left(\mathrm{Ag}_{3} \mathrm{Sb}\right)$.

\section{Regional samples}

In addition to samples from drill core, we collected samples from well-exposed areas in the vicinity of Broken Hill. Surface samples were collected from three locations to the south and southeast of the city of Broken Hill (the airport area, Black Bluffs, Thorndale gneiss) and two in the Round Hill area, which lies about $2 \mathrm{~km}$ northeast of the city (and about $8 \mathrm{~km}$ northeast of the drill-hole locations), along strike with the line of lode (Fig. 1).

Black Bluffs is an isolated hill about 800 meters long and 100 meters wide that lies to the south of the Broken Hill airport. It consists of fresh mafic granulite that locally contains isolated leucosomes with a Hbl-rich selvage, which we interpret as zones of partial melt. No obvious zones of retrogression were recognized. The four samples collected from this area $(02 \mathrm{BH} 1,2,3$, and 4) are similar, consisting of a granofelsic intergrowth of Opx, Aug, Pl, and brown Hbl.

The airport area lies to the northeast of the Broken Hill airport and consists of high-grade migmatitic metapelitic gneiss that occurs as isolated blocks within a migmatitic granite host. The three samples from this locality $(02 \mathrm{BH} 7,8$, and 9$)$ are migmatitic rocks consisting of mesoperthitic $\mathrm{Kfs}+\mathrm{Qtz}+\mathrm{Sil}+\mathrm{Crd}+\mathrm{Grt}+\mathrm{Bt}$. Biotite forms red tabular grains that have a strong preferred orientation, and fine grains rimming garnet, cordierite, and ilmenite. The former grains are inferred to have crystallized as the leucosome was solidifying, whereas the latter are retrogressive and may have formed from fluids released during crystallization of the melt portion of the migmatites. Plagioclase is rare or absent.

The Thorndale gneiss consists of metapelitic gneiss interlayered with granitic horizons. The samples we collected from the Thorndale gneiss (02BH9 and 10) have the assemblage mesoperthitic $\mathrm{Kfs}+\mathrm{Crd}+\mathrm{Sil}+$ Qtz. As with the metapelites from the airport area, biotite occurs in two texturally distinct forms.

The mafic gneiss from the top of Round Hill looks very different from that at Black Bluffs. It is mostly amphibolite, locally garnetiferous; pyroxene-bearing assemblages occur only in isolated blocks. In most places, the foliation in the amphibolite is parallel to that in the granulite blocks. The samples collected from here show various degrees of retrogression. The least-retrograded sample (02BH12) has a mineral assemblage similar to that in the mafic granulite from Black Bluffs, with brown Hbl-Opx-Aug-Pl.

One sample (02BH18) was collected from pelitic gneiss on the west side of Round Hill. The gneiss here is strongly migmatitic, with garnetiferous leucosomes and melanosomes rich in $\mathrm{Crd}+\mathrm{Sil}+\mathrm{Bt}$. Unlike the rocks from the airport area and the Thorndale gneiss, where some of the biotite appears to be texturally late, all the biotite from Round Hill gneiss forms tabular dark red-brown plates growing parallel to the foliation.

\section{Mineral Compositions}

\section{Pyroxenes}

Orthopyroxene and augite from both Black Bluff and Round Hill are weakly exsolved. To estimate their original composition, we made numerous point-analyses on line traverses across several grains. The compositions given in Table 1 are the average result of all the analyses in each section. The pyroxenes from both areas have compositions that are close to the ideal quadrilateral system, with only minor amounts of $\mathrm{Al}_{2} \mathrm{O}_{3}$ and lesser amounts of $\mathrm{TiO}_{2}$ and $\mathrm{MnO}$ (Table 1). The augite and orthopyroxene from Black Bluff are distinctly more magnesian than those from Round Hill and are more magnesian than pyroxenes from mafic rocks elsewhere in the Broken Hill region (Phillips 1980) (Fig. 5).

\section{Hornblende}

Hornblende from Black Bluffs (02BH2 and 02BH3) is magnesiohornblende ( $X_{\mathrm{Fe}}$ is in the range $0.40-0.44$; Table 1). Such compositions are among the most magnesian in the district (Phillips 1980). In both samples, the hornblende shows a slight variation in composition with Si ranging from 6.8 to 6.6 atoms per formula unit (apfu). The silica content covaries with $\mathrm{Al}$ and $\mathrm{Na}+\mathrm{K}$ along the hornblende (hbl) exchange operator: $\mathrm{hbl}=$ tremolite + edenite +1.4 tschermakite. With more than $2.0 \mathrm{wt} . \% \mathrm{TiO}_{2}$, the hornblende is also among the most titaniferous in the district (Phillips 1980)

\section{Garnet}

Garnet from the pelitic rock is dominantly almandine (Table 2). The core of the garnet is unzoned and varies by less than 1 mole $\% \mathrm{Mg} /(\mathrm{Mg}+\mathrm{Fe})$. There is a slight increase in the almandine component and decrease in the pyrope component near the margins of the garnet. This is most pronounced where garnet is in contact with biotite or cordierite. The garnet from the Airport area (02BH8) is distinctly more magnesian than that from Round Hill (02BH15), even though both rocks contain the same assemblage (Fig. 6A). The grossular component in garnet grains from all samples is low $(<0.08)$ 
TABLE 1. COMPOSITIONS OF PYROXENE AND HORNBLENDE FROM THE BROKEN HILL SUITE

\begin{tabular}{|c|c|c|c|c|c|c|c|c|c|}
\hline & \multicolumn{3}{|c|}{$02 \mathrm{BH} 2$} & \multicolumn{3}{|c|}{$02 \mathrm{BH}_{3}$} & \multicolumn{3}{|c|}{$02 \mathrm{BH} 12$} \\
\hline & Opx & Cpx & $\mathrm{Hbl}$ & Opx & Cpx & $\mathrm{Hbl}$ & Opx & Cpx & $\mathrm{Hbl}$ \\
\hline SiO, wh.\% & 52.41 & 52.19 & $45.6 \mathrm{l}$ & 51.74 & 52.43 & 45.07 & 49.01 & 50.08 & 42.32 \\
\hline $\mathrm{TiO}_{2}^{-}$ & 0.12 & 0.31 & 2.16 & 0.12 & 0.23 & 2.14 & 0.10 & 0.16 & 1.51 \\
\hline $\mathrm{Al}_{2} \mathrm{O}_{3}$ & 0.84 & 1.85 & 10.31 & 0.83 & 1.46 & 10.38 & 0.57 & 1.20 & 11.62 \\
\hline $\mathrm{Cr}_{2} \mathrm{O}_{3}$ & 0.02 & 0.02 & 0.06 & 0.00 & 0.01 & 0.07 & n.d. & n.d. & 0.00 \\
\hline $\mathrm{FeO}$ & 25.78 & 10.67 & 14.72 & 27.94 & 12.23 & 15.99 & 37.54 & 18.72 & 23.99 \\
\hline $\mathrm{MnO}$ & 0.44 & 0.21 & 0.13 & 0.46 & 0.24 & 0.15 & 0.93 & 0.45 & 0.31 \\
\hline $\mathrm{MgO}$ & 19.50 & 13.51 & 12.24 & 18.42 & 13.11 & 11.34 & 10.38 & 8.39 & 6.44 \\
\hline $\mathrm{CaO}$ & 0.84 & 20.53 & 11.09 & 0.85 & 20.49 & 11.03 & 1.06 & 20.13 & 10.54 \\
\hline $\mathrm{Na}_{2} \mathrm{O}$ & 0.02 & 0.29 & 1.86 & 0.02 & 0.25 & 1.91 & 0.03 & 0.23 & 1.45 \\
\hline $\mathrm{K}_{2} \mathrm{O}$ & n.d. & n.d. & 0.14 & 0.00 & n.d. & 0.17 & 0.01 & 0.01 & 0.91 \\
\hline$F^{2}$ & n.d. & n.d. & 0.06 & n.d. & n.d. & 0.02 & n.d. & n.d. & 0.35 \\
\hline $\mathrm{Cl}$ & n.d. & n.d. & 0.01 & n.d. & n.d. & 0.02 & n.d. & n.d. & 0.03 \\
\hline $\mathrm{F} . \mathrm{Cl}=\mathrm{O}$ & & & 0.03 & & & 0.01 & & & 0.15 \\
\hline
\end{tabular}

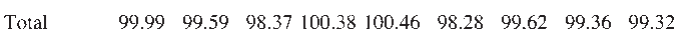

$\begin{array}{llllllllll}\text { Si apfu } & 1.968 & 1.961 & 6.664 & 1.974 & 1.966 & 6.642 & 1.987 & 1.966 & 6.411\end{array}$ $\begin{array}{lllllllllll}\mathrm{Ti} & 0.004 & 0.009 & 0.238 & 0.003 & 0.007 & 0.237 & 0.003 & 0.005 & 0.172\end{array}$

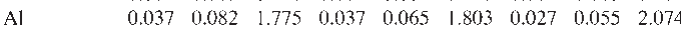
$\begin{array}{llllllllll}1 \mathrm{Al} & 0.030 & 0.039 & 1.336 & 0.028 & 0.034 & 1.358 & 0.013 & 0.034 & 1.589\end{array}$ $\begin{array}{llllllllll}{ }^{\mathrm{v}]} \mathrm{Al} & 0.007 & 0.043 & 0.439 & 0.009 & 0.031 & 0.445 & 0.014 & 0.021 & 0.486\end{array}$ $\begin{array}{llllllllll}\mathrm{Cr} & 0.000 & 0.001 & 0.007 & 0.000 & 0.000 & 0.008 & 0.000 & 0.000 & 0.000\end{array}$

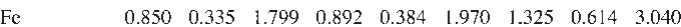
$\begin{array}{lllllllllll}\mathrm{Mn1} & & 0.014 & 0.007 & 0.016 & 0.015 & 0.007 & 0.019 & 0.032 & 0.015 & 0.039\end{array}$ $\begin{array}{lllllllllll}\mathrm{Mg} & & 1.099 & 0.757 & 2.666 & 0.988 & 0.733 & 2.491 & 0.627 & 0.491 & 1.453\end{array}$ $\begin{array}{llllllllllll}\mathrm{Ca} & & & 0.037 & 0.826 & 1.736 & 0.035 & 0.823 & 1.741 & 0.046 & 0.846 & 1.711\end{array}$ $\begin{array}{llllllllllll}\mathrm{Na} & & 0.001 & 0.022 & 0.528 & 0.001 & 0.018 & 0.547 & 0.002 & 0.018 & 0.427\end{array}$ $\begin{array}{lllllllll}\mathrm{K} & - & 0.026 & 0.000 & - & 0.032 & 0.000 & 0.000 & 0.176 \\ \mathrm{~F} & - & - & 0.028 & - & - & 0.011 & & \end{array}$

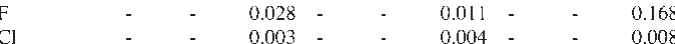
Wo $\quad 0.019 \quad 0.430-0.018 \quad 0.424-0.023 \quad 0.433 \quad-$ $\begin{array}{llllllllll}\text { Wo } & 0.019 & 0.430 & - & 0.018 & 0.424 & - & 0.023 & 0.433 & - \\ \text { En } & 0.553 & 0.395 & - & 0.531 & 0.378 & - & 0.314 & 0.251 & -\end{array}$ $\begin{array}{lllllllll}\text { En } & 0.553 & 0.395 & - & 0.531 & 0.378 & - & 0.314 & 0.251 \\ \text { Fs } & 0.428 & 0.175 & 0.451 & 0.198 & - & 0.663 & 0.315\end{array}$ $\begin{array}{llllllllll}\mathrm{Fe} /(\mathrm{Fe}+\mathrm{Mg}) & 0.44 & 0.31 & 0.40 & 0.46 & 0.34 & 0.44 & 0.68 & 0.56 & 0.68\end{array}$

$\begin{array}{llllllllll}n & 140 & 78 & 24 & 121 & 94 & 23 & 46 & 58 & 14\end{array}$

$n$ : number of point-analyses made. n.d.: not determined. Cation proportions are based upon six atoms of oxygen dfor pyroxenes and 23 for hornblende, and are expressed in atoms per formula unit (apfu). and uniform. The spessartine content in pelitic rocks adjacent to the orebody (6800-148.2 and 8315-71.1) is considerably higher than that from garnet grains in the other pelitic samples ( 0.061 to 0.081 compared to 0.005 to 0.021 ).

\section{Cordierite}

Cordierite from the airport area (02BH8) is unzoned, although there is a variation in $X_{\mathrm{Fe}}[\mathrm{Fe} /(\mathrm{Fe}+\mathrm{Mg})]$ of about 0.08 mole $\%$ depending on whether or not the cordierite grain is touching garnet or biotite, which are capable of $\mathrm{Fe}-\mathrm{Mg}$ exchange. The grain-to-grain varia-

TABLE 2. COMPOSITION OF GARNET FROM THE BROKEN HILL AREA

\begin{tabular}{|c|c|c|c|c|c|}
\hline Sample & $02 \mathrm{BH} 8$ & $02 \mathrm{BH} 15$ & $02 \mathrm{BH} 13$ & $6800-148.2$ & $8315-71.1$ \\
\hline $\mathrm{SiO}_{2}$ wt. $\%$ & 38.29 & 37.62 & 37.62 & 36.83 & 36.83 \\
\hline $\mathrm{Al}_{2} \overline{\mathrm{O}}_{3}$ & 21.46 & 21.11 & 20.66 & 20.75 & 20.81 \\
\hline $\mathrm{FeO}$ & 33.39 & 36.34 & 30.86 & 35.69 & 37.08 \\
\hline $\mathrm{MnO}$ & 0.21 & 0.91 & 3.48 & 3.58 & 2.67 \\
\hline $\mathrm{MgO}$ & 6.15 & 3.17 & 2.04 & 2.14 & 2.25 \\
\hline $\mathrm{CaO}$ & 0.27 & 1.16 & 5.44 & 0.86 & 0.48 \\
\hline Total & 99.77 & 100.32 & 100.09 & 99.83 & 100.13 \\
\hline Si apfu & 3.021 & 3.016 & 3.022 & 3.000 & 2.995 \\
\hline $\mathrm{Al}$ & 1.996 & 1.995 & 1.956 & 1.993 & 1.994 \\
\hline $\mathrm{Fe}$ & 2.203 & 2.436 & 2.073 & 2.430 & 2.522 \\
\hline $\mathrm{Mn}$ & 0.014 & 0.062 & 0.237 & 0.245 & 0.184 \\
\hline $\mathrm{Mg}$ & 0.723 & 0.379 & 0.245 & 0.26 & 0.273 \\
\hline $\mathrm{Ca}$ & 0.023 & 0.100 & 0.468 & 0.075 & 0.042 \\
\hline Total $R^{2+}$ & 2.964 & 2.977 & 3.022 & 3.010 & 3.021 \\
\hline Prp & 0.244 & 0.127 & 0.081 & 0.086 & 0.090 \\
\hline Alm & 0.743 & 0.818 & 0.686 & 0.807 & 0.835 \\
\hline Sps & 0.005 & 0.021 & 0.078 & 0.081 & 0.061 \\
\hline Grs & 0.008 & 0.034 & 0.155 & 0.025 & 0.014 \\
\hline $\mathrm{Fe} /(\mathrm{Fe}+\mathrm{Mg})$ & 0.75 & 0.87 & 0.89 & 0.90 & 0.90 \\
\hline$n$ & 6 & 10 & 4 & $\because$ & $*$ \\
\hline
\end{tabular}

$n$ : number of point-analyses made. * most Mg-rich composition from this sample. Cation proportions were calculated on the basis of 12 atoms of oxygen. Electronmicroprobe data.

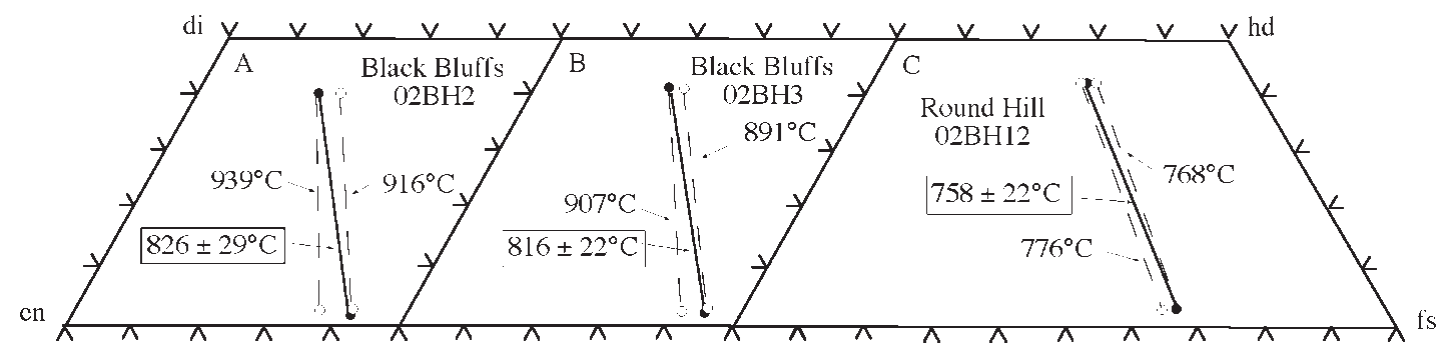

FIG. 5. Pyroxene quadrilateral showing the compositions of pyroxenes from Black Bluffs and Round Hill. Filled dots represent the compositions of pyroxenes found in each sample. Open circles show the calculated compositions that would be in equilibrium with the analyzed augite and orthopyroxene at high temperatures. Temperatures are calculated from the QUILF program of Andersen et al. (1993). 
tion is much stronger in $02 \mathrm{BH} 15$, where $X_{\mathrm{Fe}}$ of cordierite in the matrix is as much as 0.1 mole $\%$ higher than that touching the garnet (Table 3). As with the garnet, the cordierite from $02 \mathrm{BH} 8$ is distinctly more magnesian than that from $02 \mathrm{BH} 15$.

\section{Staurolite}

Staurolite from sample 8315-71.1 (Table 3) contains up to 2.9 wt. $\% \mathrm{ZnO}$. This is lower than the $\mathrm{Zn}$ content of staurolite associated with gahnite or sphalerite (Holdaway et al. 1986, Zelinski et al. 1991, Feenstra et al. 2003), which may contain 3.0 to $12.0 \mathrm{wt} \% \mathrm{ZnO}$. Neither sphalerite nor gahnite is present in sample 831571.1 , so the high $\mathrm{Zn}$ content of staurolite from this rock probably reflects high activity of $\mathrm{Zn}$ in the fluid phase.

\section{Biotite}

As with garnet and cordierite, biotite from $02 \mathrm{BH} 8$ is more magnesian than that from 02BH15 (Table 4). Biotite from both rocks have a composition similar to that from other granulite-grade terranes (Guidotti 1984). It contains around $3 \% \mathrm{TiO}_{2}$, with $02 \mathrm{BH} 15$ being slightly more titaniferous than $02 \mathrm{BH} 8$, which is in accordance with the observation of Guidotti (1984) that more ironrich biotite has a higher affinity for Ti. Biotite from both samples has about $0.5 \% \mathrm{~F}$, which is typical of biotite from granulite-grade rocks.

Biotite from near the Broken Hill orebody (6800148.2 and 8315.71.1) is lower in Ti than that from either Round Hill or the airport area, which is consistent with the lower-temperature assemblages with which it is associated. A distinctive feature about the biotite collected near the orebody is that its $\mathrm{Cl}$ content reaches up to $0.40 \%$, which is considerably higher than that of biotite from Round Hill and the airport areas.

\section{Pressure-Temperature Conditions}

\section{Pyroxene thermometry}

The pyroxene temperatures calculated for the mafic granulite from Black Bluffs using the QUILF program

\begin{tabular}{|c|c|c|c|c|}
\hline Sample & $\begin{array}{c}\text { Crd } \\
02 \mathrm{BH} 8\end{array}$ & $\begin{array}{c}\mathrm{Crd} \\
02 \mathrm{BH} 15(1)\end{array}$ & $\begin{array}{c}\mathrm{Crd} \\
02 \mathrm{BH} 15(2)\end{array}$ & $\begin{array}{c}\mathrm{St} \\
8315-71.1\end{array}$ \\
\hline $\mathrm{SiO}_{2}$ wt.\% & 48.53 & 48.03 & 48.54 & 27.77 \\
\hline $\mathrm{TiO}_{2}$ & 0.01 & 0.01 & 0.01 & 0.46 \\
\hline $\mathrm{Al}_{2} \overline{\mathrm{O}}_{3}$ & 33.85 & 33.66 & 33.90 & 52.31 \\
\hline $\mathrm{FeO}$ & 7.92 & 10.29 & 8.11 & 12.91 \\
\hline $\mathrm{MnO}$ & 0.02 & 0.10 & 0.05 & 0.11 \\
\hline $\mathrm{ZnO}$ & n.d. & n.d. & n.d. & 2.88 \\
\hline MgO & 8.71 & 6.93 & 8.27 & 1.21 \\
\hline $\mathrm{CaO}$ & 0,00 & 0.01 & 0.00 & n,d. \\
\hline $\mathrm{Na}_{2} \mathrm{O}$ & 0.06 & 0.16 & 0.15 & n.d. \\
\hline $\mathrm{K}_{2} \mathrm{O}$ & 0.00 & 0.00 & 0.01 & n.d. \\
\hline $\mathrm{F}$ & n.d. & n.d. & n.d. & 0.05 \\
\hline $\mathrm{Cl}$ & n.d. & n.d. & n.d. & 0.01 \\
\hline Total & 99.10 & 99.19 & 99.03 & 97.68 \\
\hline Si apfu & 4.946 & 4.947 & 4.955 & 7.974 \\
\hline $\mathrm{Ti}$ & 0.001 & 0.001 & 0.001 & 0.100 \\
\hline $\mathrm{Al}$ & 4.067 & 4.086 & 4.079 & 17.703 \\
\hline $\mathrm{Fe}$ & 0.675 & 0.886 & 0.692 & 3.100 \\
\hline $\mathrm{Mn}$ & 0.001 & 0.008 & 0.004 & 0.027 \\
\hline $7 . \mathrm{n}$ & - & - & & 0.610 \\
\hline $\mathrm{Mg}$ & 1.324 & 1.063 & 1.259 & 0.517 \\
\hline $\mathrm{Ca}$ & 0.000 & 0.001 & 0.000 & - \\
\hline $\mathrm{Na}$ & 0.011 & 0.032 & 0.029 & - \\
\hline $\mathrm{K}$ & 0.000 & 0.000 & 0.001 & - \\
\hline F & & & & 0.043 \\
\hline $\mathrm{Cl}$ & & & & 0.002 \\
\hline $\mathrm{Fe} /(\mathrm{Fe}+\mathrm{Mg}+\mathrm{Zn})$ & 0.34 & 0.46 & 0.36 & 0.73 \\
\hline$n$ & 6 & 5 & 3 & 5 \\
\hline
\end{tabular}

$n$ : number of point-analyses made. n.d.: not determined. Cation proportions are calculated on a basis of 18 atoms of oxygen for cordierite (Crd), and 47 for staurolite (St). Electron-microprobe data.
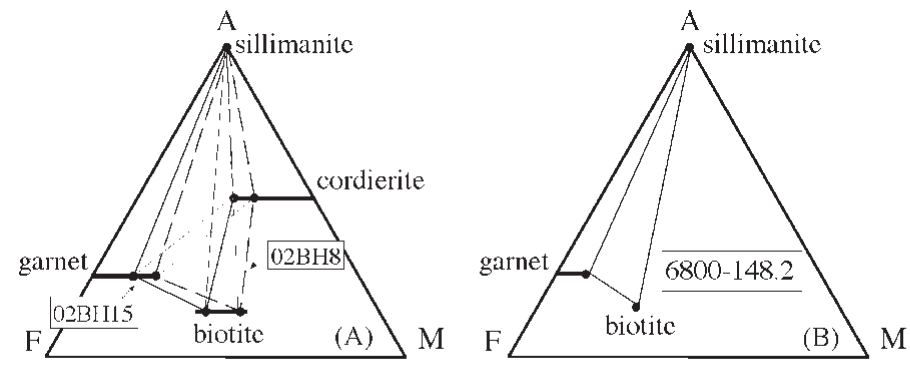

FIG. 6. AFM diagram comparing the compositions minerals from pelitic rocks. A. High-grade samples from airport area (02BH8) and Round Hill (02BH15). B and C. Samples collected from adjacent to the Broken Hill orebody. Biotite is present in sample $\mathrm{C}$ but not in equilibrium with staurolite - sillimanite and muscovite. 
of Andersen et al. (1993) range from $826 \pm 29^{\circ} \mathrm{C}$ for $02 \mathrm{BH} 2$ to $816 \pm 22^{\circ} \mathrm{C}$ for $02 \mathrm{BH} 3$ (Figs. $6 \mathrm{~A}, \mathrm{~B}$ ). The uncertainties quoted above reflect the best fit to three thermometers, (1) the solvus thermometer calculated from the augite composition, (2) the solvus thermometer calculated from the orthopyroxene composition, and (3) the $\mathrm{Fe}-\mathrm{Mg}$ exchange between augite and orthopyroxene. These temperatures are minimum estimates because the $\mathrm{Fe}-\mathrm{Mg}$ exchange closes at a much lower temperature than does the Ca exchange. During $\mathrm{Fe}-\mathrm{Mg}$ exchange, the augite becomes more magnesian, and the orthopyroxene, more iron-rich. Because at fixed temperature the solvus between orthopyroxene and augite becomes narrower with increasing $\mu_{\mathrm{FeMg}-1}$, the analyzed composition of the augite will give the highest likely temperature for the assemblage. The lowest likely temperature can be obtained by using the analyzed wollastonite content of augite and fixing $\mu_{\mathrm{FeMg}-1}$ in the augite from the analyzed enstatite content of the Opx. Using these calculation techniques in the QUILF program of Andersen et al. (1993), we get temperatures in the range of $900^{\circ} \mathrm{C}$ (Fig. 5). The filled dots and heavy lines on Figures 5A and 5B show the compositions of the analyzed pyroxenes, whereas the open circles and light lines

TABLE 4. COMPOSITIONS OF BIOTITE FROM THE BROKEN HILL AREA

\begin{tabular}{|c|c|c|c|c|}
\hline & $02 \mathrm{BH} 8$ & $02 \mathrm{BH} / 5$ & $6800-148.2$ & $8315-71.1$ \\
\hline $\mathrm{SiO}_{2}$ wt. $\%$ & 36.65 & 35.22 & 34.97 & 35.73 \\
\hline $\mathrm{TiO}_{2}^{-}$ & 3.02 & 3.20 & 2.97 & 1.33 \\
\hline $\mathrm{Al}_{2} \mathrm{O}_{3}$ & 19.22 & 19.43 & 19.32 & 19.33 \\
\hline $\mathrm{Cr}_{2} \mathrm{O}_{3}$ & 0.14 & 0.04 & n.d. & n.d. \\
\hline $\mathrm{FeO}$ & 11.49 & 8.55 & 22.54 & 21.69 \\
\hline $\mathrm{MnO}$ & 0.01 & 0.04 & 0.10 & 0.07 \\
\hline $\mathrm{MgO}$ & 17.59 & 21.26 & 6.48 & 9.32 \\
\hline $\mathrm{CaO}$ & 0.00 & 0.00 & 0.01 & 0.00 \\
\hline $\mathrm{Na}_{2} \mathrm{O}$ & 0.05 & 0.07 & 0.08 & 0.18 \\
\hline $\mathrm{K}_{2} \mathrm{O}$ & 8.87 & 8.76 & 9.88 & 9.15 \\
\hline $\mathrm{F}^{-}$ & 0.50 & 0.40 & 0.53 & 0.56 \\
\hline $\mathrm{Cl}$ & 0.07 & 0.01 & 0.43 & 0.41 \\
\hline $\mathrm{F} . \mathrm{Cl}=\mathrm{O}$ & 0.23 & 0.17 & 0.32 & 0.33 \\
\hline Total & 97.38 & 96.80 & 96.65 & 97.10 \\
\hline Si apfi & 2.666 & 2.633 & 2.636 & 2.652 \\
\hline $\mathrm{Ti}$ & 0.165 & 0.180 & 0.168 & 0.074 \\
\hline $\mathrm{Al}$ & 1.647 & 1.712 & 1.716 & 1.691 \\
\hline${ }^{\mathrm{N}} \mathrm{\Lambda l}$ & 1.334 & 1.367 & 1.364 & 1.348 \\
\hline${ }^{{ }^{1} 1} \mathrm{Al}$ & 0.313 & 0.345 & 0.352 & 0.343 \\
\hline $\mathrm{Cr}$ & 0.008 & 0.002 & - & - \\
\hline $\mathrm{Fe}$ & 1.070 & 1.329 & 1.421 & 1.347 \\
\hline $\mathrm{Mn}$ & 0.001 & 0.002 & 0.006 & 0.004 \\
\hline $\mathrm{Mg}$ & 1.246 & 0.953 & 0.728 & 1.031 \\
\hline $\mathrm{Ca}$ & 0.000 & 0.000 & 0.001 & 0.000 \\
\hline $\mathrm{Na}$ & 0.008 & 0.010 & 0.011 & 0.026 \\
\hline $\mathrm{K}$ & 0.823 & 0.836 & 0.950 & 0.866 \\
\hline $\mathrm{F}$ & 0.115 & 0.094 & 0.054 & 0.131 \\
\hline $\mathrm{Cl}$ & 0.008 & 0.001 & 0.127 & 0.052 \\
\hline $\mathrm{Fe} /(\mathrm{Fe}+\mathrm{Mg})$ & 0.46 & 0.58 & 0.66 & 0.57 \\
\hline$n$ & 13 & 21 & $\%$ & $*$ \\
\hline
\end{tabular}

$n$ : number of point-analyses made. $\quad$ n.d.: not determined. $*$ most Mg-rich composition from this sample. Cation proportions are based upon 11 atoms of oxygen. Electgron-microprobe data. show the calculated compositions. The maximum temperature of $900^{\circ} \mathrm{C}$ is somewhat above that of hornblende dehydration melting in a quartz-saturated system (Beard \& Lofgren 1991, Patiño-Douce \& Beard 1995). Because these rocks apparently melted, we contend that $900^{\circ}$ is a reasonable temperature for metamorphism at Black Bluffs.

Temperatures calculated in a similar way for the pyroxenes from Round Hill range from $768^{\circ}$ to $776^{\circ} \mathrm{C}$ (Fig. 5C). This is more than $100^{\circ} \mathrm{C}$ lower than the temperature from Black Bluffs and below the minimum temperature for dehydration melting of amphibolite (Beard \& Lofgren 1991, Patiño-Douce \& Beard 1995). Accuracy of the temperature estimate is unknown. Uncertainties include error in thermodynamic models, both of the end members and the solutions, analytical uncertainties, and uncertainty in projection from multicomponent space into the system $\mathrm{CaO}-\mathrm{FeO}-\mathrm{MgO}-\mathrm{SiO}_{2}$. Uncertainty in pyroxene thermometry is generally taken to be around $\pm 25^{\circ} \mathrm{C}$. Even considering this uncertainty, the pyroxenes from Round Hill clearly indicate a lower temperature of equilibration than those from Black Bluffs.

\section{Pelitic assemblages}

We will discuss the pelitic assemblages in two groups. First will be the rocks from Airport area and Round Hill, both of which have the assemblage Kfs + $\mathrm{Bt}+\mathrm{Sil}+\mathrm{Grt}+\mathrm{Crd}($ Fig. 6A), which means that the minerals are related by the reaction $\mathrm{Bt}+\mathrm{Sil}=\mathrm{Crd}+\mathrm{Grt}$ $+\mathrm{Kfs}+\mathrm{H}_{2} \mathrm{O}$ (or + melt). It is not clear whether biotite was a stable phase in the high-grade assemblage or whether it crystallized from reactions between the restite and melt as the melt crystallized. As a result, the P, T conditions determined from this assemblage may record the time the phases last equilibrated, rather than peak conditions. The fact that the minerals from the airport area (sample 02BH8) are distinctly more magnesian than those from Round Hill (sample 02BH15) indicates that the two samples equilibrated at different $\mathrm{P}, \mathrm{T}$ conditions along that reaction. Since this reaction has a positive slope (Spear et al. 1999), these relations indicate that the airport area equilibrated at higher $\mathrm{T}$ and $\mathrm{P}$ than Round Hill.

We calculated the $\mathrm{P}, \mathrm{T}$ conditions for these samples using the TWQ program of Berman (1991) and the database of Berman \& Aranovich (1996). The assemblage $\mathrm{Grt}+\mathrm{Crd}+\mathrm{Sil}+\mathrm{Qtz}$ defines three equilibria: two are mass-transfer equilibria involving the reaction $\mathrm{Crd}=\mathrm{Sil}$ $+\mathrm{Qtz}+\mathrm{Grt}$ (one for the Mg end-members and one for the Fe end-members), and one is an ion-exchange equilibrium, the $\mathrm{Fe}-\mathrm{Mg}$ exchange between garnet and cordierite. Because garnet becomes more Fe-enriched on cooling and cordierite more magnesian, we calculated equilibrium conditions for each rock using the most $\mathrm{Mg}$ rich garnet and Fe-rich cordierite (Fig. 7). These points provide the minimum $\mathrm{T}$ and $\mathrm{P}$ at which the garnet, cordi- 
erite, sillimanite, and quartz were in equilibrium for each rock. Because assemblages in the mafic rocks indicate a much higher temperature at both localities than the metapelitic rocks, it is likely that even the most refractory cordierite and garnet in the pelitic rocks experienced re-equilibration by $\mathrm{Fe}-\mathrm{Mg}$ exchange during cooling.

It is impossible to back-calculate the cooling path for two reasons. First, it is not clear whether the masstransfer reactions involving sillimanite maintained equilibrium with the $\mathrm{Fe}-\mathrm{Mg}$ exchange during cooling. Second, it is not known whether all the phases were present at peak $\mathrm{T}$ or whether one or more had crystallized out of the granitic melt during cooling. As a result, we show the probable conditions of crystallization for the rocks as shaded fields in Figure 7. The sample from the airport $(02 \mathrm{BH} 18)$ crystallized at $\mathrm{T}>840^{\circ} \mathrm{C}$ and $\mathrm{P}>$ $6.9 \mathrm{kbar}$, whereas the metapelitic rock from Round Hill crystallized at $\mathrm{T}>760^{\circ} \mathrm{C}$ and $\mathrm{P}>5.5 \mathrm{kbar}$.

The uncertainty for these estimates is poorly known, but is generally taken to be in the range of $\pm 50^{\circ} \mathrm{C}$ and 0.5 kbar. Much of the uncertainty in P, T estimates lies in the thermodynamic properties of the phases. Because

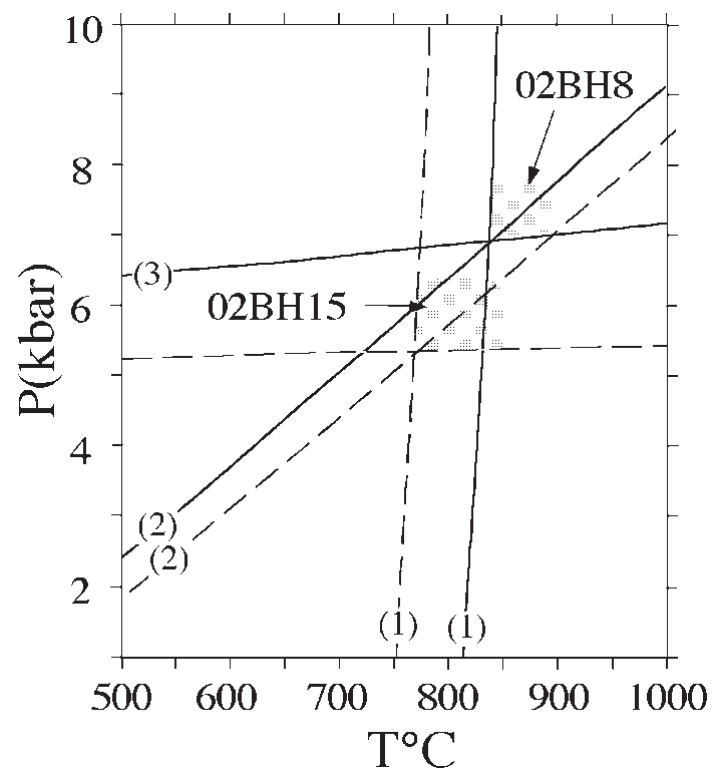

FIG. 7. $\mathrm{P}-\mathrm{T}$ diagrams showing the minimum $\mathrm{P}$ and $\mathrm{T}$ conditions for 02BH8 (solid lines) and 02BH15 (dashed lines), as determined from the assemblage cordierite - garnet sillimanite - quartz. Reaction (1): $\mathrm{Fe}-\mathrm{Mg}$ exchange between garnet and cordierite, (2): Sekaninaite ("Fecordierite") $=$ sillimanite + almandine + quartz, $(3)$ : cordierite $=$ sillimanite + pyrope + quartz. Shaded areas indicate probable equilibrium conditions for each rock. this uncertainty applies to both samples, the calculated differences between the two samples are probably real; sample $02 \mathrm{BH} 8$ equilibrated at temperatures that were $80^{\circ} \mathrm{C}$ higher and pressures that were 1.5 kilobars higher than $02 \mathrm{BH} 15$.

The second group of pelitic rocks come from adjacent to the Broken Hill orebody and contains assemblages that are lower grade than those collected at Round Hill or in the airport area. Because these rocks lack plagioclase, we cannot use the GASP barometer, and must thus estimate pressures from petrogenetic grids. Sample 6800-148.2, which has the assemblage Qtz + Kfs + Grt $+\mathrm{Bt}+\mathrm{Sil}$ (Fig. 6B), is constrained to have formed above the breakdown of muscovite and above the reaction $\mathrm{Bt}$ $+\mathrm{Sil}=\mathrm{Grt}+\mathrm{Crd}+\mathrm{H}_{2} \mathrm{O}$ (or melt) (Fig. 8). Samples 8315-71.1 and 8315-65.9, which contain the assemblage $\mathrm{Qtz}+\mathrm{Ms}+\mathrm{Bt}+\mathrm{Grt}+\mathrm{Sil}+\mathrm{St}$, are constrained to have equilibrated at or below the reaction $\mathrm{St}+\mathrm{Ms}+\mathrm{Qtz}$ $=\mathrm{Bt}+\mathrm{Grt}+\mathrm{Sil}+\mathrm{H}_{2} \mathrm{O}$, but above the reaction $\mathrm{Chl}+\mathrm{St}$ $+\mathrm{Ms}=\mathrm{Sil}+\mathrm{Bt}+\mathrm{H}_{2} \mathrm{O}$ (Fig. 8). The presence of $\mathrm{Zn}$ in the staurolite will stabilize it relative to both these reactions. For this reason, in Figure 8 we place the stability field for this assemblage to the high-temperature side of both these reactions.

The garnet-biotite temperatures for the samples adjacent to the orebody [using the garnet-biotite thermometer of Holdaway (2000)] are low compared to the temperatures inferred from the mineral assemblages; at 5 kilobars, they range from $625^{\circ} \mathrm{C}$ for $6800-148.2$ to $550^{\circ} \mathrm{C}$ for $8315-71.1$ (Fig. 8). The $\mathrm{Fe}-\mathrm{Mg}$ exchange thus records considerable cooling from the peak conditions. The lower temperature obtained from sample 8315-71.1 is consistent with the presence of late chlorite in this sample. This low-temperature closure for $\mathrm{Fe}-$ $\mathrm{Mg}$ exchange is also recorded in the rims of cordierite and garnet in the sample from Round Hill (sample 02BH15)

\section{Sulfide, sulfosalt and alloy assemblages}

Sample 8315-65.9 contains a complex suite of sulfide, sulfosalt, and alloy assemblages that probably represent the last-stage crystallization of a polymetallic melt (Frost et al. 2002). We have identified acanthite or argentite $\left(\mathrm{Ag}_{2} \mathrm{~S}\right)$, dyscrasite $\left(\mathrm{Ag}_{3} \mathrm{Sb}\right)$, and a complex domain enriched in $\mathrm{Ag}, \mathrm{Sb}$, and $\mathrm{S}$ that we were not able to characterize well because of its fine grain-size and poor polish (Fig. 9). This area could be pyrargyrite $\left(\mathrm{Ag}_{3} \mathrm{SbS}_{3}\right)$, although our semiquantitative analyses show it to be richer in Ag than pyrargyrite (Fig. 10). As an alternative, it could be an Ag-rich sulfosalt that has not been previously described, or an intergrowth of pyrargyrite, acanthite or argentite, and dyscrasite that is so fine that individual phases are not resolvable with the electron microprobe. As far as its relationship to the formation of a polymetallic melt is concerned, the identity of the $\mathrm{Ag}, \mathrm{Sb}, \mathrm{S}$ phase is not critical because its bulk composition would have been molten at 1 bar and $500^{\circ} \mathrm{C}$ 


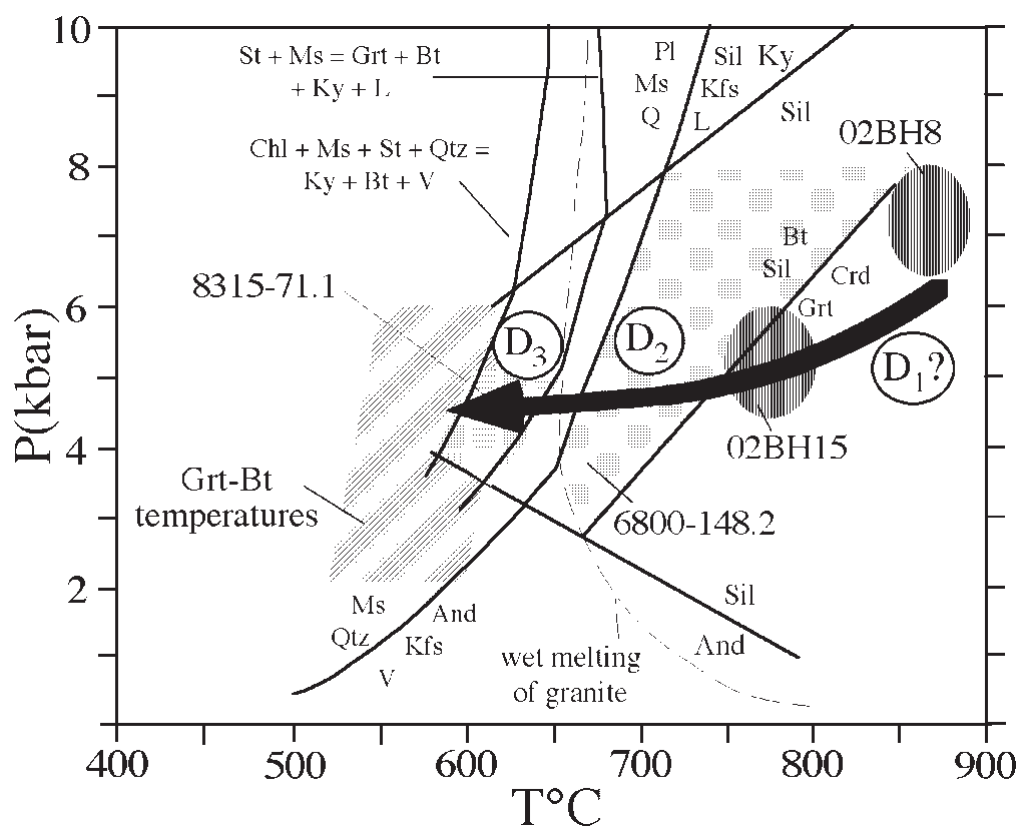

Fig. 8. Proposed P-T path for the Broken Hill orebody, showing approximate conditions for the $\mathrm{D}_{1}, \mathrm{D}_{2}$ and $\mathrm{D}_{3}$ episodes of deformation based upon samples studied in this paper. Petrogenetic grid after Spear et al. (1999)

regardless of what phases are present (Keighin \& Honea 1969).

At one bar, the bulk composition of the pyrargyrite melts congruently at $485^{\circ} \mathrm{C}$ and the eutectic between pyrargyrite and argentite lies at $465^{\circ} \mathrm{C}$ (Fig. 10) (Keighin \& Honea, 1969). Because pyrargyrite and argentite melt at a binary euctectic, rather than melting incongruently to dyscrasite (or allargentum, $\mathrm{Ag}_{6} \mathrm{Sb}$ ), the pyrargyrite-argentite join is a thermal barrier. A ternary eutectic thus must lie on the Ag-rich side of the pyrargyrite-argentite join, and it must occur at a temperature below $465^{\circ} \mathrm{C}$. The pressure effect on the melting temperature of this assemblage is not known. The experimentally determined melting reactions for sulfides have a dT/dP of $17^{\circ} \mathrm{C} / \mathrm{kbar}$ or less (Frost et al. 2002). Because melting of native $\mathrm{Sb}$ has a negative $\mathrm{dT} / \mathrm{dP}$, we consider it reasonable to assume $\mathrm{dT} / \mathrm{dP}$ slope for the melting reaction was low enough (i.e., less than $27^{\circ} \mathrm{C} /$ kbar) that these $\mathrm{Ag}-\mathrm{Sb}-\mathrm{S}$ phases were molten at the time of regional metamorphism.

\section{Discussion AND Conclusions}

\section{$P-T$ path for the Broken Hill orebody}

It is difficult to assess the peak conditions of metamorphism for the Broken Hill orebody because retro- gression associated with the pervasive $\mathrm{D}_{2}$ foliation in the area has destroyed the high-grade assemblages and reset the thermobarometers. We can get some constraints by the spatial distribution of the samples we collected from the Broken Hill area. Round Hill lies about 10 kilometers south of the Opx-in isograd (Phillips 1980), whereas the western end of the orebody lies about $13 \mathrm{~km}$ to the southeast of the isograd (Fig. 2). In contrast, the airport area is about $20 \mathrm{~km}$ southeast of the isograd. If there were a relatively constant metamorphic field-gradient across the area, the peak metamorphic conditions at Round Hill would have occurred at slightly lower temperature than those on the western end of the orebody. Similarly, the P, T in the airport area would have been slightly higher than those found at either locality.

The highest temperatures we record at Round Hill are $c a .770^{\circ}$ from the pyroxene thermometry in the relict mafic granulites. Pattison et al. (2003) argued that the boundary between amphibolite facies and granulite facies is probably marked by vapor-absent melting reactions, which for moderate pressures lie between 800 and $850^{\circ} \mathrm{C}$. This view suggests that the pyroxene-based temperatures from Round Hill probably reflect extensive $\mathrm{Fe}-\mathrm{Mg}-\mathrm{Ca}$ exchange between the pyroxenes fluxed by fluids during partial retrogression to amphibolite accompanying the $\mathrm{D}_{2}$ deformation. The true peak temperature 

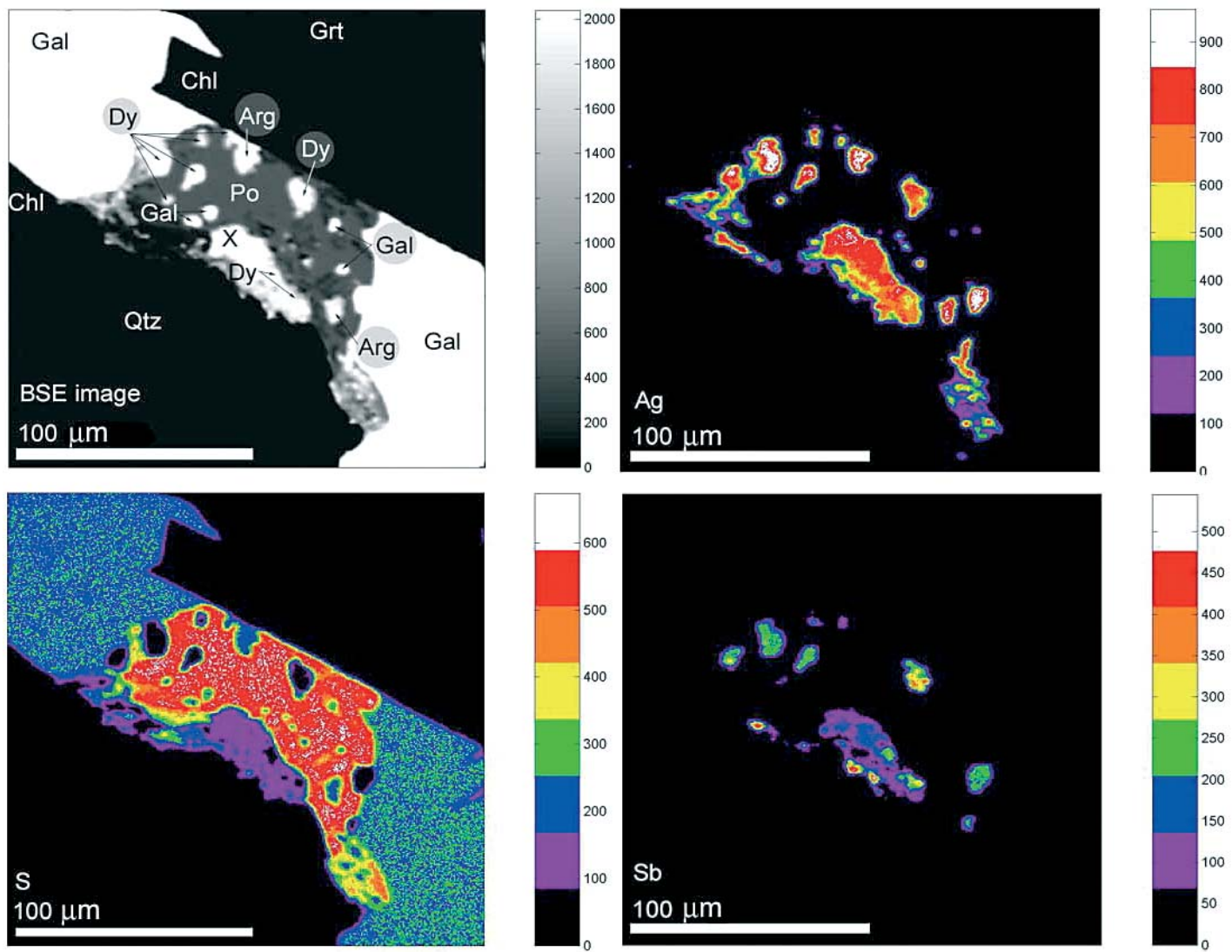

FIG. 9. Back-scattered electron (BSE) and X-ray images showing sulfide, sulfosalt and alloy assemblages in 8315-65.9 A. BSE image, B. X-ray map of sulfur abundance, C. X-ray map of Ag abundance, D. X-ray map of Sb abundance. Symbols: Arg: argentite or acanthite, Dy: dycrasite, Gal: galena, Po: pyrrhotite; X indicates an area enriched in Ag, Sb, and S.

probably was around $850^{\circ} \mathrm{C}$, which is still somewhat lower than the $\mathrm{ca} .900^{\circ} \mathrm{C}$ temperatures recorded in the mafic granulites at Black Bluffs, which were less intensely affected by $\mathrm{D}_{2}$.

The peak pressure is difficult to estimate because the pelitic assemblages, from which pressure can be estimated, last equilibrated at temperatures about $100^{\circ} \mathrm{C}$ below the peak temperature (as indicated by pyroxene thermometry). The metapelitic rocks from Round Hill give a minimum pressure of around 5 kilobars, but that was the pressure at $750^{\circ} \mathrm{C}$, when the cordierite, garnet, sillimanite, quartz (and probably biotite) last equilibrated. Similarly, pelitic rocks from the airport area give a minimum pressure of 7 kilobars (at $850^{\circ} \mathrm{C}$ ). Because the airport area lies seven km "upgrade" from the ore horizon, it is reasonable to assume that the pressure was somewhat higher there than at the western end of the orebody. Because of these uncertainties, we estimate that the pressure conditions for peak metamorphism of the orebody were somewhere between 5 and 7 kilobars.
We have taken a conservative near-isobaric cooling path for the area on Figure 8. This choice is based upon the minimum pressure of the Round Hill pelitic rocks and upon the likely upper pressure for the staurolitebearing pelitic rocks in drill hole 8315 . This is in agreement with the conclusion that the cooling path of the migmatites at Round Hill was nearly isobaric (Powell \& Downes 1990).

\section{Melt evolution of the Broken Hill orebody}

If the peak metamorphism at Broken Hill was around $850^{\circ} \mathrm{C}$, as suggested by the melting of mafic granulites in the Round Hill area, then the orebody would have been partially molten at this time. This temperature is well above the eutectic for the pure system FeS-PbS$\mathrm{ZnS}$ (Mavrogenes et al. 2001). The presence of minor components that could flux sulfide melts, including Ag, $\mathrm{Sb}, \mathrm{As}$, and $\mathrm{Cl}$ (see Frost et al. 2002, Mungall \& Brenan 2003) would have induced much greater melting in the 


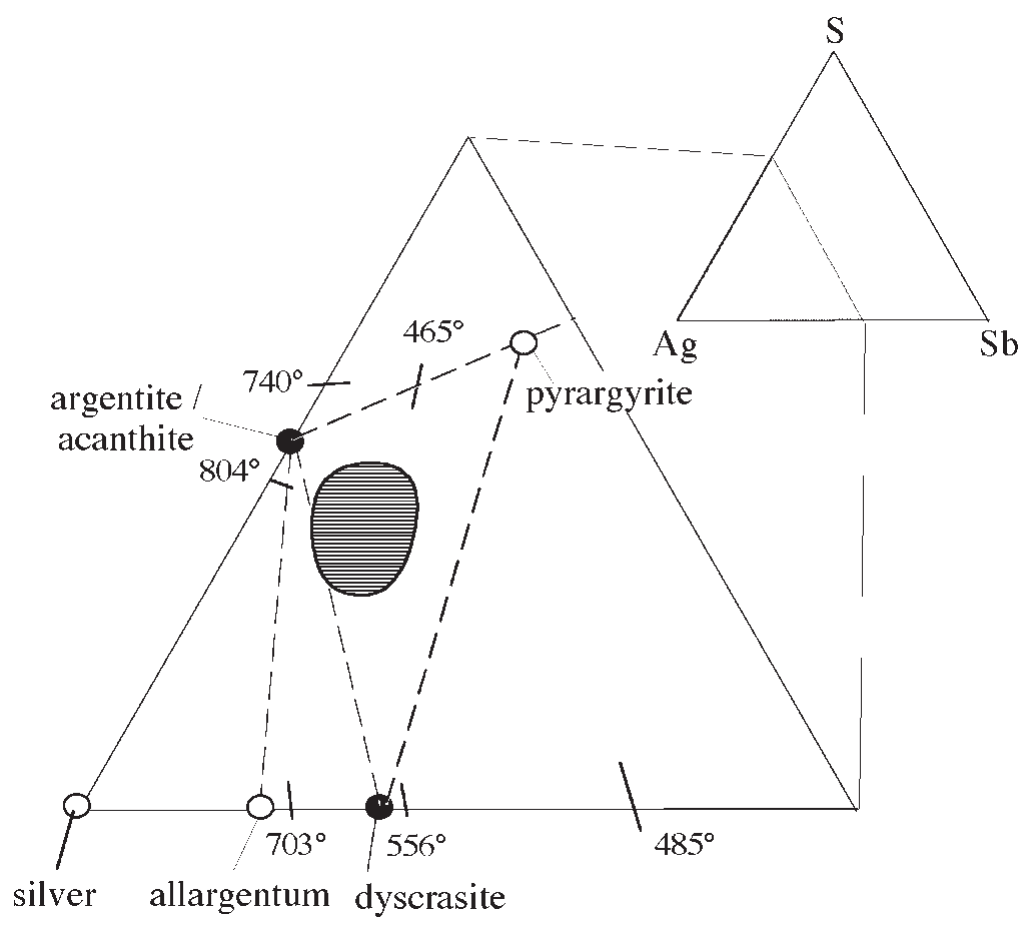

FIG. 10. Diagram showing the minerals stable in the Ag-rich portion of the system Ag$\mathrm{Sb}-\mathrm{S}$. Dark dots represent minerals identified in Figure 9. Pyrargyrite is shaded because its presence is possible but not substantiated. Open dots indicate phases that are present in the system, but which have not been identified in sample 8315-65.9. Shaded field gives the composition range in area $\mathrm{X}$ of Figure 9 . Temperatures (in ${ }^{\circ} \mathrm{C}$ ) refer to the euctectics and peritectics in binary systems, the location of which is marked by short lines (data from Keighin \& Honea 1969).

natural system than is apparent from the phase diagram of the pure system. Because the eutectic in the FeS$\mathrm{PbS}-\mathrm{ZnS}$ system lies near the $\mathrm{PbS}-\mathrm{FeS}$ join, these melts would be enriched in $\mathrm{Pb}, \mathrm{Fe}$ (and probably $\mathrm{Ag}, \mathrm{As}, \mathrm{Au}$, $\mathrm{Cu}$, and $\mathrm{Sb}$ ), whereas the restite would be enriched in $\mathrm{ZnS}$ (Mavrogenes et al. 2001). This high-T melt was also enriched in Mn, as indicated by plumose Mn-silicates associated with some melt inclusions (Sloan 2000).

Textures in sample 8315-65.9 suggest that a sulfide melt was still present at the time of $\mathrm{D}_{3}$ deformation of this rock. The composition of this melt was quite different from that of the high-temperature melt. Sphalerite is lacking from 8315-65.9, whereas the low-melting metals $\mathrm{Ag}$ and $\mathrm{Sb}$ are relatively abundant. We contend that these differences were caused by differentiation of the polymetallic melt that resulted in the depletion of $\mathrm{Zn}$, As and S from the melt. This depletion resulted in the loss of sphalerite and arsenopyrite as crystallizing phases, perhaps via peritectic reactions. The loss of sulfur, perhaps simply by degassing of $\mathrm{H}_{2} \mathrm{~S}$, resulted in the crystallization of the native alloy dyscrasite from the melt.

\section{Duration of the melt at Broken Hill}

Our study shows that a polymetallic melt was present in the Broken Hill orebody from the temperatures of peak metamorphism $\left(\mathrm{ca} .850^{\circ} \mathrm{C}\right)$, at least until the time of $\mathrm{D}_{3}$, during which time the terrane cooled to $\mathrm{ca}$. $600^{\circ} \mathrm{C}$. Available geochronological constraints indicate that this occurred over a period of one to 20 million years (Fig. 3). Because it seems unreasonable that the terrane would have cooled isobarically through $c a$. $250^{\circ} \mathrm{C}$ during only a million years, we contend that the most likely duration was on the long end of the scale, perhaps 10 to 20 million years. During this period of time, a mobile, differentiating polymetallic melt was present in the rocks. During this period any deformation experienced by the rocks would certainly have led to movement of the melt into structurally favorable sites, away from the site of generation. 


\section{ACKNOWLEDGEMENTS}

Research on this project was supported by NSF grant EAR-0125113. We gratefully thank the Perilya Mining Company for providing us to access of drill cores through the Broken Hill orebody, Barney Stevens for identifying the key areas to sample in the Broken Hill area, and John Mavrogenes for his assistance in the sampling. The manuscript benefitted greatly from reviews by Barney Stevens, Ken Hickey, and an anonymous reviewer. BRF thanks Dugald for the many fine hours we spent talking about canoeing. Perhaps now that he is retired, we can actually take some trips together!

\section{REFERENCES}

Andersen, D.J., Lindsley, D.H. \& Davidson, P.M. (1993): QUILF: a Pascal program to assess equilibria among $\mathrm{Fe}-$ $\mathrm{Mg}-\mathrm{Mn}-\mathrm{Ti}$ oxides, pyroxenes, olivine, and quartz. Comput. Geosci. 19, 1333-1350.

BEARD, J.S. \& LOFGREN, G.E. (1991): Dehydration melting and water-saturated melting of basaltic and andesitic greenstones and amphibolites at 1,3, and 6.9 kilobars. J. Petrol. 32, 365-401.

BERMAN, R.G. (1991): Thermobarometry using multi-equilibrium calculations: a new technique, with petrological applications. Can. Mineral. 29, 833-855.

\& ARANovich, L.Y. (1996): Optimized standard state and solution properties of minerals. 1. Model calibration for olivine, orthopyroxene, cordierite, garnet and ilmenite in the system $\mathrm{FeO}-\mathrm{MgO}-\mathrm{CaO}-\mathrm{Al}_{2} \mathrm{O}_{3}-\mathrm{SiO}_{2}-$ $\mathrm{TiO}_{2}$. Contrib. Mineral. Petrol. 126, 1-24.

BINNS, R.A. (1964): Zones of progressive regional metamorphism in the Willyama complex, Broken Hill district, New South Wales. J. Geol. Soc. Aust. 11, 283-330.

DuTch, R \& HAND, M. (2003): Delmarian metamorphism in the Curnamona Province: constraints from the prograde "retrograde" shear zones. In Broken Hill Exploration Initiative 2003. Geosci. Aust. Rec. 2003/13, 36-37 (abstr.).

Feenstra, A. Ockenga, E., Rhede, D. \& Wiedenbeck, M. (2003): Li-rich zincostaurolite and its decompressionrelated breakdown products in a diaspore-bearing metabauxite from East Samos (Greece): an EMP and SIMS study. Am. Mineral. 88, 789-805.

Frost, B.R., MAvrogenes, J.A. \& Tomkins, A.G. (2002): Partial melting of sulfide ore deposits during medium- and high-grade metamorphism. Can. Mineral. 40, 1-18.

Gibson, G. M. \& CZARnota, K. (2003): Structural history of the Bimbowrie inlier: role of low-angle shear zones and wider implications for tectonothermal evolution of the Willyama Supergroup. In Broken Hill Exploration Initiative 2003. Geosci. Aust. Rec. 2003/13, 50-52 (abstr.).

GuidotTi, C.V. (1984): Micas in metamorphic rocks. In Micas (S.W. Bailey, ed.). Rev. Mineral. 13, 357-467.
GuLson, B.L. (1984): Uranium-lead and lead-lead investigations of minerals from the Broken Hill lodes and mine sequence rocks. Econ Geol. 79, 476-490.

Gustafson, J.K., BurRell, H.C. \& GarRetTy, M.D. (1950): Geology of the Broken Hill ore deposit, Broken Hill, New South Wales, Australia. Geol. Soc. Am., Bull. 61, 13691437.

Hand, M., Rutherford, L. \& Barovich, K. (2003): Garnet $\mathrm{Sm}-\mathrm{Nd}$ age constraints on the timing of tectonism in the southwestern Curnamona province: implications for existing models and correlations. In Broken Hill Exploration Initiative 2003. Geosci. Aust. Rec. 2003/13, $65-68$ (abstr.).

Harrison, T.M. \& McDougall, I. (1981): Excess ${ }^{40} \mathrm{Ar}$ in metamorphic rocks from Broken Hill, New South Wales: implications for ${ }^{40} \mathrm{Ar} /{ }^{39} \mathrm{Ar}$ age spectra and the thermal history of the region. Earth Planet. Sci. Lett. 55, 123-149.

Hobbs, B.E., Archibald, N.J., Etheridge, M.A. \& Wall, V.J. (1984): Tectonic history of the Broken Hill block, Australia. In Precambrian Tectonics Illustrated (A. Kröner \& R. Greiling, eds.). E. Schweizerbart'sche Verlagsbuchhandlung, Stuttgart, Germany (353-368).

HodGson, C.J. (1975): The geology and geological development of the Broken Hill lode in the Broken Hill Consolidated mine, Australia. III. Petrology and petrogenesis. $J$. Geol. Soc. Aust. 22, 195-213.

Holdaway, M.J. (1971): Stability of andalusite and the aluminum silicate phase diagram. Am. J. Sci. 271, 97-131.

(2000): Application of new experimental and garnet Margules data to the garnet-biotite geothermometer. $\mathrm{Am}$. Mineral. 85, 881-892.

Dutrow, B.L. \& SHORE, P. (1986): A model for the crystal chemistry of staurolite. Am. Mineral. 71, 11421159 .

Keighin, C.W. \& HoneA, R.M. (1969): The system Ag-Sb-S from $600^{\circ} \mathrm{C}$ to $200^{\circ} \mathrm{C}$. Mineral. Deposita $4,153-171$.

KRETZ, R. (1983): Symbols for rock-forming minerals. Am. Mineral. 68, 277-279.

LaING, W.P., MaJoRIBANKS, R.W. \& RutLand, R.W.R. (1978): Structure of the Broken Hill mine area and its significance for the genesis of the orebodies. Econ. Geol. 73, 1112-1136.

LAWRENCE, L.J. (1967): Sulphide neomagmas and highly metamorphosed sulphide deposits. Mineral. Deposita 2, 5-10.

MajoRibanks, R.W., RutLAnd, R.W.R., GLEN, R.A. \& LAING, W.P. (1980): The structure and tectonic evolution of the Broken Hill region, Australia, Precamb. Res. 13, 209-240.

Mavrogenes, J.A., MacIntosh, I.W. \& Ellis, D.J. (2001): Partial melting of the Broken Hill galena-sphalerite ore experimental studies in the system PbS-FeS-ZnS- $\left(\mathrm{Ag}_{2} \mathrm{~S}\right)$. Econ. Geol. 96, 205-210. 
Mungall, J.E. \& BRENAN, J.M. (2003): Experimental evidence for the chalcophile behavior of the halogens. Can. Mineral. 41, 207-220

Nutman, A.P. \& EhLers, K. (1998): Evidence for multiple Paleoproterozoic thermal events and magmatism adjacent to the Broken Hill $\mathrm{Pb}-\mathrm{Zn}-\mathrm{Ag}$ orebody, Australia. Precamb. Res. 90, 203-238.

PAGE, R.W. \& LAING, W.P. (1992): Felsic metavolcanic rocks related to the Broken $\mathrm{Hill} \mathrm{Pb}-\mathrm{Zn}-\mathrm{Ag}$ orebody, Australia: geology, depositional age, and timing of high-grade metamorphism. Econ. Geol. 87, 2138-2168.

Stevens, B.P.J. \& GiBson, G.M. (2005): Geochronology of the sequence hosting the Broken Hill $\mathrm{Pb}-\mathrm{Zn}-\mathrm{Ag}$ orebody, Australia. Econ. Geol. (in press).

PARR, J. M. \& Plimer, I.R. (1993): Models for Broken Hilltype lead-zinc-silver deposits. In Mineral Deposit Modeling.(R.V. Kirkham, W.D. Sinclair, R.I. Thorpe \& J.M. Duke, eds.). Geol. Assoc. Can., Spec. Pap. 40, 253288.

Patiño Douce, A.E. \& BeArd, J.S. (1995): Dehydrationmelting of biotite gneiss and quartz amphibolite from 3 to 15 kbar. J. Petrol. 36, 707-738.

Pattison, D.R.M. (1992): Stability of andalusite and sillimanite and the $\mathrm{Al}_{2} \mathrm{SiO}_{5}$ triple point: constraints from the Ballachulish aureole, Scotland. J. Geol. 100, 423-446.

Chacko, T., Farquhar, J. \& McFarlane, C.R.M. (2003): Temperatures of granulite-facies metamorphism: constraints from experimental phase equilibria and thermobarometry corrected for retrograde exchange. $J$. Petrol. 44, 867-900.

PhILliPs, G.N. (1980): Water activity changes across an amphibolite-granulite facies transition, Broken Hill, Australia. Contrib. Mineral. Petrol. 75, 377-386.

\& WALL, V.J. (1981): Evaluation of prograde regional metamorphic conditions: their implications for the heat source and water activity during metamorphism in the Willyama Complex, Broken Hill, Australia. Bull. Minéral. 104, $801-810$

Powell, T. \& Downes, J. (1990): Garnet porphyroblast-bearing leucosomes in metapelites: mechanisms, phase diagrams and an example from Broken Hill, Australia. In High-Temperature Metamorphism and Crustal Anatexis (J.R. Ashworth \& M. Brown, eds.). Unwin Hyman, London, U.K. (105-123).
Raetz, M., Krabbendam, M. \& Donaghy, A.G. (2002): Compilation of $\mathrm{U}-\mathrm{Pb}$ zircon data from the Willyama Supergroup, Broken Hill region, Australia: evidence for three tectonostratigraphic successions and four magmatic events? Aust, J. Earth Sci. 49, 966-983.

SlOAN, M. (2000): Relationships between the Ore and Enclosing Rocks at Broken Hill, NSW. Honours. thesis, Australian National Univ., Canberra, Australia.

Spear, F.S., Kohn, M.J. \& Cheney, J.T. (1999): P-T paths from anatectic pelites. Contrib. Mineral. Petrol. 134, 17 32

Stevens, B.P.J., Barnes, R.G., Brown, R.E., Stroud, W.J. \& WILLIS, I.L. (1988): The Willyama supergroup in the Broken Hill and Euriowie blocks, New South Wales. Precamb. Res. 40/41, 297-327.

STÜWE, K. \& EhLERS, K. (1997): Multiple metamorphic events at Broken Hill, Australia. Evidence from chloritoid-bearing parageneses in the Nine-Mile mine region. J. Petrol. 38, 1167-1186

Tonelli, M., Woodhead, J. \& Hergt, J. (2003): Pb-Pb dating of garnet, staurolite and tourmaline by a stepwise dissolution technique. In Broken Hill Exploration Initiative 2003. Geosci. Aust. Rec. 2003/13, 188-191 (abstr.).

White, S.H., Rothery, E., LiPS, A.L.W. \& BARClay, T.J.R. (1995): Broken Hill area, Australia, as a Proterozoic fold and thrust belt: implications for the Broken Hill base-metal deposit. Trans. Inst. Mining Metall. (Sect. B: Appl. Earth Sci.) 104, B1-B17.

Willis, I. L., Brown, R.E., Stroud, W.J. \& Stevens, B.P.J. (1983): The Early Proterozoic Willyama Supergroup: stratigraphic subdivision and interpretation of high to lowgrade metamorphic rocks in the Broken Hill Block, New South Wales. J. Geol. Soc. Aust. 30, 195-224.

WiLson, C.J.L. \& Powell, R. (2001): Strain localization and high-grade metamorphism at Broken Hill, Australia: a view from the Southern Cross area. Tectonophysics 335, 193 210 .

Zelinski, E., Froese, E. \& Gordon, T.M. (1991): Metamorphic petrology of the $\mathrm{Fe}-\mathrm{Zn}-\mathrm{Mg}-\mathrm{Al}$ alteration at the Linda volcanogenic massive sulfide deposit, Snow Lake, Manitoba. Can. Mineral. 29, 995-1017.

Received January 15, 2004, revised manuscript accepted December 7, 2004. 